\title{
READING SCRIPTURE THROUGH A MYSTICAL LENS
}

\begin{abstract}
In addition to the unprecedented interest in spirituality in recent decades, both at a popular level and also as an academic discipline, there has also been a resurgence of research dealing with spirituality and scripture. It is readily acknowledged that the hegemony of the historical-critical method is no longer tenable. As a method which sees the text as an artifact of history, there is minimal, if any, attempt to understand the experience of those who produced the text; it concentrates on a literal interpretation, at the expense of the polysemous nature of scripture. Contemporary scriptural studies, however, have witnessed a sea-change in interpretive methods of such magnitude, that it is difficult to keep up with current scholarship in this field. Within this paradigm shift, the importance of a spiritual reading of scripture has now come to the fore. More specifically, reading scripture through a mystical lens, as originally seen, inter alia, in the works of Origen, has taken its place, if not centre stage, at least on the stage, and no longer in the wings. Utilising the insights of a French Carmelite, Elisabeth Catez, a mystical reading of Paul exemplifies this new, yet ancient, hermeneutical method.
\end{abstract}

\section{INTRODUCTION}

It is important to note that practically all training in biblical hermeneutics during the last three centuries concentrated on the purely intellectual, whereas preEnlightenment study of scripture combined intellectual knowledge with a spiritual sensitivity which could foster a mystical reading of scripture. Modernity produced scripture specialists who banished mystical reading from the academy. In addition, modernity, with its Newtonian-type mind set contributed to an atrophy of the spiritual faculties, and texts which were meant to resonate at many levels of meaning were reduced to the literal sense. Scientific and analytical scholarship was uneasy about studying the specifically religious or mystical origins of early Christianity. Fortunately, however, during the last few decades the academy is freeing itself from the fetters of determinism,

Prof. Celia Kourie. Department of Christian Spirituality, Church History and Missiology, Unisa. E-mail: kouricet@unisa.ac.za.

Acta Theologica

2011 Suppl 15: $132-153$

ISSN 1015-8758

http://dx.doi.org/10.4314/actat.v31i1S.8

(C) UV/UFS

<http://www.uovs.ac.za/ActaTheologica> 
and mystical commentaries are now commonplace in university and seminary training. ${ }^{1}$ A major reason for this change of perspective is the fact that biblical hermeneutics has witnessed a major heterodox methodological explosion within the last few decades. ${ }^{2}$ The serious limitations of the historical-critical method as a methodological tool for interpreting the bible have been acknowledged: its atomistic and disintegrative nature; the lack of understanding of the documents as literary wholes; the concentration on the pre-literary phase which grinds the tradition up into small pieces and prohibits a more holistic meaning of the text in its wider setting; the idea of scripture as an object to be dissected, rather than a life-giving revelation; the positivistic framework from within which the method operates; the reductionist view of myth - the list could be continued. ${ }^{3}$ Little attempt is made to understand the experience of those who produced the text and as such scholars ignored the very raison d'être of these writings of the early Christian communities. Thurston (2005:55; cf 2000:2) describes this as the

human experience of God mediated by the person of Jesus of Nazareth .... The New Testament ... records spiritual experience. This presumes that 'spiritual experience' is real.

1 Recent publications of earlier works witness to this phenomenon, for example, De Lubac (2009). This is of particular importance, given the increasing interest in the four-fold sense of scripture. See Cousins (2000) for an analysis of Christian mysticism and the fourfold sense.

2 Merely to enumerate certain New Testament methodologies shows the multidimensional nature of current scholarship. For example, structuralism; readerresponse theory; speech-act theory; rhetorical criticism; sociological analysis, Girardian exegesis; liberation approaches, including contextual, materialist, feminist, womanist, men's and gender studies; cultural exegesis; ecological interpretation; pluralist interpretation, literary criticism, which includes psychological, aesthetic, spiritual and mystical hermeneutics (cf Kourie 1995:174). Of particular importance in our global world are studies that offer an associative reading of scriptures from diverse traditions which would effect a revitalised understanding of the one through dialogue with the others. Whereas the forms and concepts of scripture are culture-specific and the individual socio-historical aspects cannot be overlooked, nevertheless the reception of scripture is similar enough to allow the diverse scriptures to be fruitfully compared, so that the experience of one tradition can shed light on another. Thus critical approaches from potentially incompatible orientations may give complementary readings of a given text. For example, comparative studies of parables and koans; Christology in the light of Mahayana Buddhism; the notion of a Christian Vedanta, with reference to the Bhagavad gita; the concept of the Cosmic Person in Hindu, Christian and Islamic scriptures these and many other hermeneutical keys could be utilised.

3 Of course, this is not to deny its validity; in spite of its many shortcomings, the historical-critical method has certainly been, and continues to be of vital importance in understanding the provenance of the text (cf Kourie 1985). 
Theissen (2007:23) confirms the importance of the experience of the divine, and argues that a more open approach to the Bible will facilitate this possibility. ${ }^{4}$ Historical criticism concentrated on the sense intended by the author, to the detriment of allegorical and other 'more-than-literal' approaches (Schneiders 2005a:293; cf 2005b:65). Contemporary biblical studies has witnessed a major shift from a mechanistic to a holistic paradigm, enabling the text to come to life as transformative and life-changing, and this has contributed to the rediscovery of the text as dynamic medium rather than static object. Against this background, therefore, the aim of the present paper is firstly, to look at current interest in spirituality and scripture; and secondly to offer a reading of scripture through a mystical lens, with particular reference to Origen's (c.185-c.253) contribution and also that of a relatively unknown modern mystic, Elisabeth Catez (1880-1906).

\section{SPIRITUALITY AND SCRIPTURE}

Whilst there has been a sea-change of considerable magnitude with regard to academic interest in the relationship of scripture and spirituality, as mentioned above, this is by no means an altogether new phenomenon. As Bullough (1954:343) states:

During the last ten years or so there has been a greatly increased awakening, among Christians all over the world to the importance of the spiritual sense of Scripture, to the value of the symbolic approach to Scripture, and to a consciousness of the influence of biblical symbolism upon the spiritual life of the Christian.... It is all the more important that we should have in our minds clear ideas about the nature of the spiritual sense, especially in view of the neglect of such studies during the nineteenth century and until recent times. ${ }^{5}$

Bullough (1954:343-350) gives a brief history of biblical symbolism from the early church to 1950 , with particular reference to Catholic encyclicals. This falls outside the ambit of the present discussion, although reference to Origen's contribution will be made below. For present purposes it is interesting to look at contemporary statements regarding spirituality and scripture against the backdrop of the above-mentioned. For example, Schneiders (2005b:6566) points out that one of the reasons for a renewal of interest in Scripture and spirituality is the fact that there has been an increasing demand for a "spiritually

4 Of particular importance for Theissen is the Bible in dialogue with a pluralistic world. See in this connection his discussion of the Bible in relation to the major religious traditions (Theissen 2007:75-149).

5 Proceedings from a conference on Scripture and the Spiritual Life at Bishton Hall, Stafford, UK, September 1953. 
relevant interpretation". Schneiders offers a reading of the Bible that is "both responsible to contemporary canons of interpretation and productive of a true biblical spirituality" (Donahue 2006:82). Of prime importance is the attempt to work between two poles, namely, a "reading of the biblical text that is faithful to its historical and literary context" and a "realization that this is a sacred text, which leads to human transformation ... [and avoids] a distanced historicism ... (and) an ungrounded piety" (Donahue 2006:83). Such an approach is gaining ground in the academy. ${ }^{6}$

Today, biblical scholars are rediscovering the genius if not the actual methods of spiritual exegesis. It belongs to the area of hermeneutics rather than exegesis, that is, to interpretation which is based on critical exegesis but not arrested at the analytical level. As late twentiethcentury biblical scholars moved beyond exclusively historical critical approaches they focused first on the biblical writers as authors with theological and other agendas pursued by various rhetorical strategies. This led to a focus on the text itself as literature. And this led inevitably to a focus on the reader whose interaction with the text gives rise to meaning. Readers do not simply work on texts but the text works on the reader, for good or ill. The pragmatics of reading came into focus and this is the sphere of spiritual interpretation (Schneiders 2005a:294).

In order to locate the foregoing within recent theories of spirituality, a working definition of the latter is necessary. Literature dealing with definitions of spirituality is prolific; ${ }^{7}$ for present purposes, spirituality can be described as "... the concern of all who feel drawn to the 'fullness of humanity' and is the capacity ... [for self-transcendence] through knowledge and love ..." (Schneiders 1986:266;) In addition, it is necessary to be aware of the fact that spirituality

is unavoidably ambiguous, referring to (1) a fundamental dimension of the human being, (2) the lived experience which actualizes that dimension, and (3) the academic discipline which studies that experience (Schneiders 1989:678).

Concerning biblical spirituality, among the definitions offered, that of Bowe (2003:19) succinctly summarises the basic elements:

6 In this connection, the University of the Free State, Bloemfontein, SA., introduced a Masters degree in Biblical Spirituality, January 2008. St Augustine College of SA, Johannesburg, SA, offers Biblical Spirituality as a component of the Masters degree in Christian Spirituality. Recent literature witnesses to an increased awareness of this dimension (cf Neyrey 2007; Greenman, Larsen \& Spencer 2007).

7 A summary of the current discussion has been given in Kourie (2006:22-26; cf 2009:151,154). 
Biblical spirituality ... defines our lived faith experience that draws on the special biblical treasure-house of stories, images, prophetic challenges, and prayers and on the ultimate example of the life and death of Jesus for its understanding of God and for its convictions about the meaning of human existence.

Undoubtedly, spiritual interpretation of scripture lends itself to the charge of "eisegesis", and admittedly, there may well be some truth in this allegation in certain cases. Therefore respect for established methods of exegesis, and an ability to "step back" from the text and be alert to its semantic potential, without projecting one's own pre-conceived notions, is important. ${ }^{8}$

By way of summary, the new openness to biblical spirituality effects a greater "clarification of the existential meaning" of what is offered in the text (Waaijman 2002:871; cf Waaijman 1992). The "reciprocal relation" that exists between the reader and the text, and the "personal awakening" that is effected as a result of the revelation of the text are now more fully recognised (Waaijman 2002:766-767). Drawing on the insights of Levinas and Ricoeur, Waaijman (2002:771) states:

By understanding, the text is reactualised and this actualization constitutes an essential

aspect of the text ... The scriptural meaning imprints itself in the life and contact of the reader ... Thus, appropriation of the essential meaning of the text in one's life witnesses to the power and efficacy of the encounter with scripture. ${ }^{9}$

\section{MYSTICISM AND SCRIPTURE}

\subsection{The nature of mysticism}

In order to examine scripture through a mystical lens, it is important to have a preliminary understanding of the nature of mysticism itself. ${ }^{10}$ Mysticism, at its

8 See Donahue (2006:84-85) for a valuable discussion of Sandra Schneiders' utilisation of the insights of Ricoeur (1976) concerning the semantic autonomy of a text: "its meaning is not limited to the 'intention' of an original author, yet this autonomy does not imply that 'authorial meaning has lost all significance'; there will always be a dialectical relationship between authorial intention and subsequent meaning....The 'effective history' (Wirkungsgeschichte) of texts and traditions continues beyond the canonical scriptures and can continue to influence the interpretation and appropriation of the originating narratives."

9 See De Villiers (2010) for an example of "transformation" in the gospel of Mark.

10 Whilst mysticism is closely related to spirituality the two cannot be equated. Perhaps it is true to say that mysticism is the acme of the spiritual path, and 
core, has been described as "the radical surrender of self to the loving embrace of the Other who is at the foundation of all life, the One to whom we owe our very existence" (Perrin 2005:443). For Christian mysticism the constitutive element is "immediacy of contact with the Deity" (Deissmann 1926:149). In his classic treatment, Inge (1989) lists twenty-six definitions of mysticism. Yet, in the final summing-up of his research, nearly fifty years later, Inge (1947:8) succinctly encapsulates the crux of its meaning, "Mysticism means communion with God, that is to say with a being conceived as the supreme and ultimate reality". Consciousness of the divine presence can be expressed as either oneness with God, unio; or fellowship with God, communion. Of prime importance in any analysis of mysticism is its experiential nature. It is the experience of union with God. In Christian mysticism, it is Christ who articulates this union through the Spirit. Furthermore, mystical consciousness [is] "meta-consciousness" 11 - a consciousness beyond - which is "... the copresence of God in our inner acts, not as an object to be understood or grasped, but as the transforming Other". This is further elaborated: "He (She) is active in the human agent as the source, or co-author, of our acts of experiencing ... knowing and loving" (McGinn 2008:47). ${ }^{12}$ A greater understanding of the nature of mysticism and appreciation for its relevance, particularly for interpreting scripture is nevertheless not accepted in all quarters of the academy and society. Rigid orthodoxy, whether academic or ecclesial, prefers to expel the mystically inclined, with the disclaimer that mysticism is syncretistic and leads to relativism. The anti-mystical stance is exemplified in attempts to expose the threat of mysticism as

both anti-Scriptural and a contradiction of the evangelical view that the Bible is the one and only ultimate criterion of truth about God and our relation to Him .... [Mysticism] is a 'non-Christian philosophy' (Johnson 1988:11.14).

Allied with this is a prejudice against mysticism, which considers it to be a Greek influenced, heretical branch of Christianity. Paradigmatic of such views is a certain strand of Protestantism associated with, inter alia, Ritschl,

therefore spirituality should lead to mystical transformation. The experiential nature of mysticism is paramount.

11 McGinn refers here to the terminology of Merton (1968:74). In addition, he draws on the work of Lonergan $(1972 ; 1957)$ for this concept.

12 There has been increased interest in the phenomenon of mysticism, particularly from the mid-nineteen seventies, characterised particularly by a philosophicalanalytical- critical approach. With deep acuity this approach brings to light the differences both in form and content between various mystical traditions. The role of logic and reason in the mystical experience is clarified and the different methodological presuppositions with respect to mystical states are more clearly analysed. Katz $(1978 ; 1983 ; 2000)$ is representative of such an approach. 
Troeltsch, von Harnack and the neo-orthodoxy of Barth and Brunner. ${ }^{13}$ Clearly mystics have been, and are still viewed with distrust, in certain quarters, as disturbers of the institutional order. Lee (1989:105) illustrates:

The curious contradiction mysticism has historically proved to be for the Church. It has been the wellspring of both saints and schismatics, the hallmark of luminaries and lunatics alike. It has been a force for the active upbuilding of the body of Christ and an impetus to the countercurrents of sectarianism, anti-nomianism and quietism. It has issued in theologies of impeccable Trinitarian monotheism and in the heterodoxy of pantheism.

In addition, mysticism has often been seen as

an essentially individualistic, acultural, ahistorical, asocial, acontextual, anomian (if not primarily antinomian) phenomenon ... its decisive characteristics are said to be its ... transcending of prevailing cultural, intellectual, social and theological norms and influences (Katz 2000:7) ${ }^{14}$.

Given the afore-mentioned, it is nevertheless a fact that the study and appreciation of mysticism has spread rapidly and has gained a social significance that was lacking three or four decades ago. ${ }^{15}$ We are now confronted with a movement that can no longer be ignored. It is time to be open and see mysticism as a divine gift, which will be particularly beneficial for interpreting scripture in contemporary biblical studies. A renewed understanding of scripture can bring about renewal at many levels. Scripture has many layers of meaning to be discovered in order for its truths to be illuminated. Of course, a mystical reading of the text is not new; a brief discussion of the work of Origen illustrates this fact.

\subsection{Origen (c 185-253)}

In the Christian tradition, we are reminded of the seminal contribution of Origen (c 185-253) and his teaching on the multiple meanings of scripture.

13 See Kourie (1992) for a summary of this position.

14 This paradigm, according to Katz $(1978 ; 1983 ; 2000)$ is deficient. In contrast, he maintains that all mystical experience is contextual. Katz's contextual, constructivist approach has been analysed in Kourie 1992. Katz (2000) develops his contextual approach in his detailed analysis of mystical scriptural interpretation in diverse religious traditions.

15 A recent conference, Mysticism without Bounds held at Christ University, Bangalore, January 2011, with participants from over 30 countries, in the fields of philosophy, theology, science, business, education, art, spirituality, etc., witnesses to this phenomenon. 
It is outside the scope of the present article to discuss this in depth, suffice it to offer the following observations. Origen is clearly a scriptural exegete of the highest order in antiquity; in addition he combines "the roles of exegete, theologian, and mystic with great creativity and intellectual power" (McGinn \& Ferris McGinn 2003:23). Origen expanded and elaborated the well-known two-fold sense of scripture (historical and spiritual or allegorical) into a three-fold model, viz., historical, moral and spiritual, in accordance with the anthropological understanding of body, soul and spirit of his time. "Passing over the somatic or material meaning of the text, Origen concentrates on allegory, moral and typological meanings" (Wansbrough 2010:45). Origen's scriptural hermeneutic led the way forward for a mystical interpretation of scripture, and the ascent to the Divine:

The scribe of the gospel is one who knows how, after studying the narrative of

events, to ascend to the spiritual realities without stumbling [and then] gallop through the vast spaces of mystic and spiritual understanding (Commentaries on Matthew 10:14 and Romans 7:11, in McGinn \& Ferris McGinn 2003:25).

Although he was not the first to illustrate the allegorical or typological meanings of scripture, he changed the "balance of power" by emphasizing the hidden or mysterious meaning above the literal meaning (Wansbrough 2010:45).

For Origen and other early scriptural exegetes, all of scripture was seen to be the word of God, written for the purpose of salvation; Christ is the ultimate meaning of the scriptures for individuals and the church. The text has a plurality of possible meanings. Later medieval exegesis expanded Origen's three-fold model to the well-known four-fold exposition: literal (historical), allegorical (theological), tropological (moral) and anagogical (eschatological). ${ }^{16}$ Origen's Word-centred mysticism is seen constantly in his commentary on the Song of Songs:

If there is anyone anywhere who has at some time burned with this faithful love of the Word of God; if there is anyone who has received the sweet wounds of him who is the chosen dart, as the prophet says; if there is anyone who has been pierced with the loveworthy spear of his knowledge, so that he yearns and longs for him by day and by

16 Slightly similar methods of exegesis can be found in other religious traditions, for example, the "kabbalistic theory of the four types of exegesis of the Torah, known by the acronym PaRDeS; the tradition of ta'wil and tafsir among Sufis; and the threefold method of Vedic interpretation that deciphers the text as referring to the adhiyajna (sacrificial acts), to the adhidaiva (gods) and to the adhyatma (self) (Katz 2000:18). 
night, can speak of nought but him, would hear of nought but him, can think of nothing else, and is disposed to no desire nor longing nor yet hope, except for him alone - if such there be, that soul then says in truth: 'I have been wounded by love' (Comm. On the Song, III. 8, in Louth1981:67).

Origen is clearly the first major Christian scripture scholar and his mystical hermeneutic witnesses to the multivalent meaning to be found in the Bible. The

superabundance of meaning... (is) embedded in the words of the sacred text ... (and)... the modern reader ... may, by reading Origen, be challenged to grow in spiritual wisdom (O'Keefe 2010:11).

Origen's mystical exegesis was taken up by later patristic and medieval and medieval writers. ${ }^{17}$ Of course, the allegorical method of Origen does not fall easily upon modern ears, accustomed to sharp, Cartesian logic. However,

the cultural distance separating us from such sources should not negate the lessons we might still learn from them.... [This] allegorical reading ...[is] not a competitor to historical-critical approaches, but ... a method grounded in distinctive textual spirituality manifesting certain similarities to poetry (Burrows 2002:169).

Polysemous readings of scripture, just as with poetry, open doors and windows to a hidden dimension. The contribution of Origen is such that he has been called the founder of "intellectualist mysticism".

In this tradition, contemplative union is the union of the nous, the highest point of the soul, with God through a transforming vision. And in such union the nous finds its true nature .... (Louth 1981:74).

Intellectual mysticism, however, does not negate affective mysticism. The "noetic and erotic dynamism of the soul" is addressed, as for example, in the prologue to the Commentary on the Song, "(a)fter realizing the beauty of the divine Word, we can allow ourselves to be set on fire with saving love, so that the Word itself deigns to love the soul in which it has encountered longing for it" (quoted in McGinn \& Ferris McGinn 2003:36). The final goal of such an "anagogic, or uplifting, reading of the Bible ... is divinization of the soul" as Origen says:

For Christians see that with Jesus human and divine nature begin to be woven together, so that by fellowship with divinity human nature might

17 Dante Alighieri claimed that his work, the Commedia, should be understood in the light of the four-fold interpretive strategy used for understanding scripture. Collins (1989:109) makes the point that Dante claimed to write as God wrote, although he never explicitly stated this. 
become divine, not only in Jesus, but also in all those who believe and go on to undertake the life which Jesus taught, the life which leads everyone who lives according to Jesus' commandments to friendship with God and fellowship with Jesus (Against Celsus 3.28 in McGinn \& Ferris McGinn 2003:38). ${ }^{18}$

A mystical hermeneutic of scripture is one in which a direct experience of God, or Ultimate Reality, or the One is the end result. The difficulty of trying to express the inexpressible, to put into language that which is totally beyond language and even beyond thought, cannot be overestimated. Nevertheless this does not deter mystics of all traditions from attempting to describe their experience and to articulate its reality. In spite of the ineffability of the experience itself, mystics offer an array of texts in which the experience and its meaning are described. An interesting facet of a mystical reading of scripture is that whilst in certain cases, mysticism is clearly seen as an alternative to organised religion, on the other hand, there are telling examples of mystical experiences that resonate with the mystic's religious tradition. In the latter case, there is a linkage of personal experience with revealed truth, in which what was known and described in the scriptures is experienced personally. A mystical reading of scripture witnesses to the life-giving power of the texts. The text breaks the spell of previously-held presuppositions, correcting and revising established views, and thus provoking a new self-understanding, effecting transmutation of character and daily life. A mystical hermeneutic therefore concentrates more on the synchronic aspect of the text, rather than historical, linear, or mechanistic considerations. It can be classified as an immanental hermeneutic. The text is now more readily acknowledged as a mediation of meaning which takes place as event in the reader and provides as it were a "door" between different dimensions of consciousness. Often the journey into new dimensions necessitates entering into the silence, the void - the inexpressible. Word and silence are irrevocably intertwined. In the light of the fore-going, the thought of Paul will now be briefly examined through a mystical lens.

18 Based on 2 Peter 1:4, the invitation to become sharers of the divine nature resulted in what the early mothers and fathers of the church called "deification" or "theosis". This concept occurs frequently in the patristic texts. For example, Clement of Alexandria states, "God's Logos has become human that humankind might be able to grasp how it can attain to being God" (Protrepticus 1.9, in Pannikar 1989:193, n.39). See also Meyendorff (1989) for an excellent discussion of theosis in the Eastern christian tradition. Underhill ([1911]/1961:416) points out that mystics who are drawn to a transcendent/metaphysical approach speak of deification, whereas those following a more intimate/personal approach speak of spiritual marriage. 


\subsection{A Mystical Reading of Paul: the insights of Elisabeth Catez (1880-1906)}

The problematic concerning mysticism in Paul has gained prominence since the end of the nineteenth century. Much of the discussion has centred on the Pauline formula "in-Christ". ${ }^{19}$

It is not my intention here to discuss the various contributions to the debate concerning mysticism in Paul, as this has been summarized elsewhere. ${ }^{20}$ Instead, taking cue from Tavard (1981:561), who comments on the fact that very few scholars turn to the Christology of the mystics "... as a valid and valuable source for the exploration of Christ as the centre of a permanently contemporary experience", the aim of this section is to discuss Paul through the lens of a relatively modern mystic, Elisabeth Catez (1880-1906).

Elisabeth Catez was born into a French military family and after her father's death in 1887, the family took up residence close to the monastery of the Discalced Carmelites in Dijon, where Elisabeth eventually began the life of an enclosed Carmelite in August 1901..$^{21}$ Early in 1905, certain symptoms of Addison's disease occurred, and in the spring of 1906 Elisabeth was permanently installed in the convent infirmary, where she died on November 9

19 Deissman (1892:84; cf 1926) considered the term "in Christ" as the kernel of Paul's thought: Paul's communion mysticism is expressed in his life in the spiritual Christ. The seminal contribution of Schweitzer (1931) is best expressed in his thesis that the "in-Christ" motif takes precedence over "righteousness by faith" in Paul. The latter is "... a subsidiary crater which has formed within the main crater, the mystical doctrine of redemption through the being-in-Christ. Whilst the 'outward appearance is still of the transient world ... the reality is already that of the eternal world" (1931:110). For an analysis of ecclesial, eschatological and corporate interpretations of "in-Christ" see Kourie (1985). Beiringer (2011) in an unpublished paper delivered at the recent conference, Mysticism without Bounds, held at Christ University, Bangalore, discusses Pauline mysticism from the perspective of participation, with reference to 2 Cor 5:14-21.

20 See Penna (1996:235-273) for a historical survey of the debate concerning Pauline mysticism.

21 The Carmelite foundation at Dijon dates back to 1605. It was the third Carmelite monastery to be founded in France, after Paris and Pontoise. The first prioress was Mother Anne of Jesus, a companion of Teresa of Avila. In 1790 the community was expelled from their house by virtue of the revolutionary laws suppressing monastic vows. The Carmel of Dijon was restored in 1866, housed in a very old building in the poorest quarter of the city. It was on this site that the monastery where Elisabeth entered in 1901 was built. In 1979 the community transferred to Flavignerot, 13 kilometres southeast of Dijon, where there is a small museum dedicated to Elisabeth. 
1906, at the age of twenty-six. ${ }^{22}$ Elisabeth's mysticism has been gleaned from what can be considered a few occasional writings and retreats. In addition, three hundred and forty-six letters of Elisabeth have been preserved. ${ }^{23}$

How can Elisabeth contribute to a mystical reading of scripture? Her scriptural formation was almost non-existent. There is no evidence to suggest that any courses on scripture were offered to the Carmelites at that time, or that Elisabeth had access to commentaries on scripture. The state of biblical studies in the Catholic church of the time was in disarray. Although there was a spirit of renewal among biblical scholars, the Bible, already little known among Catholics in general, was further restricted by ecclesiastical authority as a result of the Modernist crisis. Elisabeth had access to the New Testament, but only to the book of Psalms from the Old Testament. Nevertheless, many references to the latter are to be found in her writings: these would have come from her spiritual reading and various retreat conferences. In spite of the aforementioned, Elisabeth Catez is a scriptural mystic par excellence, and scripture provides the authority upon which her spiritual doctrine is built. ${ }^{24}$ Elisabeth's reading of the text is synchronic, not diachronic; her interest lies in the text as it is, not its historical provenance. Elisabeth's emphasis is on

22 Elisabeth suffered extremely as a result of Addison's disease, which had only been identified in 1849. Although in severe pain, Elisabeth received no analgesics, no morphine, and an operation was considered to be of no value. Georges Chevignard, Elisabeth's brother-in-law, who was a doctor, was not convinced that Elisabeth received sufficient medical care, a view that Elisabeth ardently refuted (De Meester 1980:348-9; 351; 430). Today, Addison's disease can be kept under control with hydrocortisone tablets.

23 The various writings of Elisabeth, from which her mystical thought has been gleaned are: a diary; seventeen personal notes; lists of references from the bible or other authors; one hundred and twenty-four poems; four spiritual treatises; and three hundred and forty-six letters. The publication of the critical edition of the Complete Works by De Meester (1980;1985a;1985b) provides a scholarly and scientific analysis of Elisabeth's writings which is in stark contrast to certain previous hagiographical works. Elisabeth's retreats have been translated into Arabic, Korean, Vietnamese, English, German, Dutch, Italian, Spanish, Portuguese, Czech, Japanese, Polish and some into Russian.

24 An exact estimation of biblical quotations in the writings of Elisabeth is difficult, owing to the fact that there are implicit as well as explicit citations in her work. 156 quotations from the Old Testament, and 769 from the New Testament are found in Elisabeth's writings. It is clear that she has a predilection for John and Paul: the former is quoted 217 times and the latter 395 times. The synoptic gospels feature very little, and the miracles and parables of Jesus are not included. It is noteworthy that in the last seven months of her life, Elisabeth quotes Paul 230 times and John 100 times. Marion (1981:62) correlates in an informative manner the use of scripture by Elisabeth with the main events in her life, and particularly the extreme suffering that she endured. 
the illuminatory function of scripture which confirms and explains experience, rather than in its philological or scientific status. Elisabeth often juxtaposes several texts when quoting from memory and the biblical foundation of her writings is clearly evident in certain cases which are practically a string of references from Scripture. Elisabeth, in accordance with her own Carmelite charism, was selective in her choice of scriptural teaching. Her choice of texts would have been influenced by the choice and spiritual exegesis of her mystical mentors, such as John of the Cross, Teresa of Avila, and Ruusbroec; her profound adherence to scripture concurs with the tradition of the Carmelites, dating back to the twelfth century, when Albert of Jerusalem wrote the Carmelite Rule, itself a clear witness to scripture. Elisabeth's radical hermeneutic manifests her epistemological activity of discrimination and integration: she does not spend time on what is peripheral and marginal, but penetrates to the essence, namely Christ himself. Elisabeth's mystical reading of Paul in particular is a constant thread in her writings; ${ }^{25}$ as articulated in her mystical conformity to Christ.

\subsection{Conformity to Christ}

The centrality of Christ in the life and thought of Elisabeth is axiomatic from even a cursory survey of her writings. She was captivated by Paul, in particular his teaching on conformity to Christ (Rom 8:29). ${ }^{26}$ As expressed in her poetry, Jesus is the "Splendour of the Father" (De Meester 1985b:360,364) who, incarnated in the individual, leads her to the intra-Trinitarian life of glory and praise. For Elisabeth, Jesus teaches what it means to know the Father in mystical simplicity and to live life in a divine way. It is noteworthy that Elisabeth had inscribed on the back of her profession crucifix, "It is no longer I who live,

25 It is apposite at this juncture to comment briefly on Elisabeth's style of writing. Her initial writings have been described as 'sentimental' (von Balthasar 1956:19). A certain artificiality and stiltedness is evident, together with rather a 'flowery' style, which was characteristic of the piety of the age. Nevertheless, Elisabeth's later writings, coloured more and more by biblical thought, portray little if any of this superficiality of style. Decourtray (1980:24) commenting on the scriptural nature of Elizabeth's writing, incisively points out that at the end of the nineteenth and beginning of the twentieth century, such biblical language would have appeared quite new and almost revolutionary. Bearing in mind the limited knowledge of the Bible among ordinary Catholics of this era, it is true to say that in a certain sense, Elisabeth prefigured much of the scriptural renewal prevalent in the Catholic church since 1943.

26 Elisabeth was very systematic in her reading of Paul. She took detailed and systematic notes, linking Paul's words to the great mysteries of faith that captivated her, particularly the idea of incorporation into Christ, and living as a "praise of God's glory". The latter, and her love for the letter to the Ephesians, coloured Elisabeth's mystical doctrine, particularly in her final days of suffering. 
but Christ who lives in me" (Gal 2:20b) - a clear indication of her desire to be transformed into the image of Christ. Jesus is firstly a mode/ par excellence for her life as a Carmelite nun. Those who are models for their followers become ideals; their characters become categorical and their biographies didactic. Whilst the historical specificity is of importance,

... the historically particular is not ... the essence of the conception of the model's self-hood. Rather, the historically specific is only the particular occasion for the iteration of transcendent, objective and trans-historic 'truths' (Katz 1982:247).

Secondly, Jesus, for Elisabeth, is not only a model and paradigm, but also the exemplar and enabler, who shows what it means to be in the image and likeness of God. Jesus is the one who effects a radical transformation of the total person, a "Christification", which leads to human authentication and divinization.

The quintessential way in which Elisabeth interprets the tenets of scripture is by interiorisation, by assimilating and actualizing them in her own life. The Christification process takes place within the depths of her being: for example, the incarnation is not only the historical birth and life of Christ, but also a

... perpetual cosmic and personal process ... (the) everlasting bringing forth, in the universe and in the individual ascending soul, of the divine and perfect life, the pure character of God, of which the one historical life dramatized the essential constituents (Underhill [1911]/1961:118).

Thus the "breakthrough" of the divine and archetypal life into history facilitates living life at a higher level than merely of the senses. Interiorisation forms a major principle by which Elisabeth interprets the historical events of Christianity and transmutes their meaning into a meta-historical realm. This is what could be called a mysticism of the "historical event", by means of which such mimetic or contemporizing re-enactment transforms the historical founding events of Christianity into deep mystical experience. Cousins (1983:166) describes this as follows,

In this type of consciousness, one recalls a significant event in the past, enters into its drama and draws from it a spiritual energy, eventually moving beyond the event towards union with God.

For Elisabeth, the powerful Pauline expression "in Christ" or "in Christ Jesus" determined her life as a Christian and as a Carmelite; this formula is a synthesis of her entire doctrine, and transformation in Christ forms the bedrock of Elisabeth's scriptural mysticism. This is effected in everyday living: a quotidian mysticism. It does not presuppose extraordinary states of consciousness, although there may well be "mystical touches" at times, when 
the window of eternity is opened, and the fresh breeze of the Spirit allows a glimpse into Reality. However, as Dunn (1977:195) speaking of Christmysticism states,

... union with Christ for Paul is not characterised by lofty peaks of spiritual excitment and ecstasy, experiences of visions, revelations ... or high inspiration but more typically by self-giving love, by the cross union with Christ is nothing if it is not union with Christ in his death. ${ }^{27}$

The burden of the argument to date centres on the fact that Christ is not merely paradigmatic for Elisabeth, but also the one who effects transformation. As mentioned above, both these facets of her Christological mysticism are evident in Elisabeth's understanding of suffering. True to the spirit of Carmel, Elisabeth saw suffering as the patrimony of her order, the salvific efficacy of which was seen to radiate beyond the confines of the cloister to help effect the redemption of mankind. Allusions to suffering are not merely fragmentary or incidental in the writings of Elisabeth but pervade her mystical doctrine. The concept of radical renunciation is a strong leitmotif, based on the cross and resurrection of Jesus which forms a dominant conceptual dynamic for her own incredible suffering. With the progressive deterioration of her health, Elisabeth's identification with the suffering Christ intensified. Owing to her scriptural understanding of the meaning of the cross, she bore her excruciating pain with deep patience and love. The secret of her strength is to be found in the fact that, in line with many mystics of her time and ours, Elisabeth realized that the road of the cross is at the same time the way of beatitude. However, bearing her pain with fortitude does not mean that Elisabeth was lulled into a kind of platonic detachment; Christian faith does not sweep its adherents up and out of the struggle and misery of life into some non-involved spiritual or intellectual relationship with God. In stark contrast, the gospel shows God as sweeping out of eternity in order to be totally and passionately involved in the brokenness of life (Thomsen 1988:252). Following Paul, Elisabeth is aware that human weakness is not an obstacle, on the contrary, it provides the ambience for divine activity. This was Paul's experience in Corinth (2 Cor

27 Whilst Elisabeth does not recount extraordinary mystical experiences, nevertheless, she does mention that during a visit to her spiritual director, Pere Vallee, in 1900, she became aware of the presence of the indwelling Trinity; this experience was to ground her spirituality within the great mystery of the Trinity for the remainder of her short life. In fact, she is known as Elisabeth of the Trinity. Notwithstanding this mystical grace, Elisabeth is what could be called a passion mystic. In other words, hers is a mystical identification with the passion and crucifixion of Jesus. A recent festschrift for James D.G. Dunn (Oropeza, Robertson \& Mohrmann 2009) offers an excellent survey of Pauline thought, but unfortunately an examination of Paul's mystical thought is missing, a fact that is not uncommon in New Testament scholarship, even in the $21^{\text {st }}$ century. 
11:23-33) and led to his doctrine of power in weakness (2 Cor 4:7-11), namely that all spiritual strength comes from God alone. Paul's own afflictions are presented as a didactic model in several instances: he carries death in his body so that the life of Jesus can be manifested (2 Cor 4:10); he suffers to bring comfort to the Corinthians in order that they in turn might suffer and share Christ's suffering (2 Cor 1:5); he commends the Philippians for suffering as an example to their opponents (Phil 1:29-30) and the Thessalonians for following his example in suffering (1 Thess 1:5-6). By urging his readers to follow the example of Jesus in his suffering, Paul is calling them into the power of the gospel. Therefore, the power/weakness paradox was not thought out in an academic, philosophical and detached manner, but resulted from the trials of Paul's ministry and the consequent realization of his own utter nothingness and the allness of God. In similar fashion Elisabeth's intuitive grasp accrues from her own painful illness. For Elisabeth, therefore, it is not a question of mere reflection on the words of Paul, or speculation regarding the mystery of suffering. Elisabeth's acceptance of her own personal "crucifixion" epitomizes the summation of a life which consistently sought to be divested of self. She teaches that pain and suffering can be transfigured; more exalted states of consciousness can exist contemporaneously with intense states of suffering. Crises of mind and body help effect maturation, propelling women and men forward to a state beyond the habitual pre-conditioning of sense, to a stage where emotional and intellectual responses are determined by a higher power. Elisabeth's conformity to Christ, therefore is conditioned by mystical identification with Christ crucified and risen, the didactic value of which comes not from theological speculation, but from her own personal experience. Elisabeth learnt by experience that sickness and suffering do not necessarily lead to debilitation. Paul's

connection of an extremely negative symbol, execution on the cross, with the most positive symbols of salvation and redemption, makes it possible to reduce avoidance reactions with respect to suffering - a presupposition of help for the weak, ill and those in need of aid and the constructive handling of suffering in themselves (Theissen 1987:395).

Therefore, although Elisabeth did not read learned works of biblical exegesis, she discovered the transformative power of a mystical reading of scripture. Hers was not merely a passive reading, but a personal involvement with the text, allowing herself to be "described" and "narrated" by the words of the Bible, particularly the teaching of Paul. Elisabeth allowed scripture to effect an "ontological metamorphosis" in her life, which she then in turn communicated to her readers. In this respect, Elisabeth witnesses to the "semantic potential" of the text, which, according to Ricoeur (1980;1981) elicits the participation of the reader. Elisabeth's mystical lens, characterized 
by a freshness of approach, a keen selectivity and perspicacity, illustrates the breadth and depth of the richness that is scripture.

\section{CONCLUSION}

By way of conclusion, the following points can be made: firstly, since the inner world was neglected for so long in the academy, the symbolic, transformative and mystical aspects of scripture were minimized. Modernity, and in particular, a certain type of academic superiority contributed to this state of affairs, and texts, which were meant to resonate at many levels of meaning were reduced to the literal sense only. Clearly, this situation is changing and the re-emergent study of scripture and spirituality is bearing fruit, in biblical study groups, in church circles, in non-ecclesiastical groups and in the academy. As scholars re-visit the commentaries of the early centuries of Christianity, the richness of a mystical reading of scripture is clearly evident. Secondly, a mystical hermeneutic concentrates on the synchronic aspect of the text, and the myths of the Bible are seen to represent a living dialectic of our inner history, providing meaning for life - the symbols of scripture are constantly being transformed and revitalized. Fortunately, therefore, scripture interpretation is freeing itself from the fetters of determinism, and the limits of rationalism are becoming more apparent. Thirdly, reading scripture through a mystical lens, particularly as exemplified by Elisabeth Catez's interpretation of Paul, effects mystical illumination, not only for herself, but also for her readers. Elisabeth witnesses to the semantic potential of the text, in which the possibility of multiple readings comes to the fore. The illuminatory and existential significance of scripture is given due recognition. Thus, a return to our mystical roots, and a rediscovery of our mystical heritage, will open doors to a more translucent understanding of the ancient texts, an understanding which will impact positively not only in the academy, but in society as a whole.

\section{BIBLIOGRAPHY}

BEIRINGER, R.

2011. St. Paul, Participation and Mysticism. Keynote Paper given at 'Mysticism Without Bounds', International conference on Mysticism. Christ University, Bangalore, India: January 5-8, 2011.

BOWE, B.

2003. Biblical Foundations of Spirituality. Touching a Finger to the Flame. Oxford: Rowman \& Littlefield Publishers, Inc.

BULLOUGH, S.

1954. The Spiritual Sense of Scripture. The Life of the Spirit. The Scriptures and the Spirit. 8 (92-93):343-353. 
Burrows, M.

2002. "To Taste with the Heart". Allegory, Poetics, and the Deep Reading of Scripture. Interpretation April 2002:168-180.

Collins, J.

1989. Dante. Layman, Prophet, Mystic. New York: Alba House.

Cousins, E.

1983. Francis of Assisi: Christian mysticism at the crossroad. In: S. Katz (ed), Mysticism and religious traditions, (New York: Oxford University Press), pp. 163-190.

2000. The Fourfold Sense of Scripture in Christian Mysticism. In S. Katz (ed), Mysticism and Sacred Scripture (Oxford: Oxford University Press), pp 118-137.

Deissmann, A.

1892. Die Neutestamentliche Formel, 'In Christo Jesu'. Marburg: NG Elwert.

Deissmann, A.

1926. Paul: A Study in Social and Religious History. London: Hodder \& Stoughton.

De LuBAC, $\mathrm{H}$.

2009. Medieval Exegesis. Vol 3. The Four Senses of Scripture. Grand Rapids, Michegan. Translation from Exegese medieval, 3: Les quatre sens de l'ecriture. Paris: Editions Montaigne, by E.M. Macierowski.

De Meester, C (Ed.)

1980. Elisabeth de la Trinite, Carmelite. J'ai trouve Dieu. Oeuvres Completes.Tome Ib. Paris: Les Editions du Cerf.

1985a. Elisabeth de la Trinite, Carmelite. J'ai trouve Dieu. Oeuvres Completes. Tome la. Paris: Les Editions du Cerf.

1985b. Elisabeth de la Trinite, Carmelite. Jái trouve Dieu. Oeuvres Completes. Tome II. Paris: Les Editions du Cerf.

De Villiers, P.G.R.

2010. The Powerful transformation of the young man in Mark 14:51-52 and 16:5. HTS Teologiese Studies/Theological Studies. 66(1) Art \#89. 7 pages. D01:10.4102/ hts.v66i/893

DONAHUE, J.

2006. The Quest for Biblical Spirituality. In B. Lescher \& E. Liebert (eds), Exploring Christian Spirituality. Essays in Honor of Sandra M. Schneiders. IHM. (New York: Paulist Press), pp 73-97.

DunN, J.

1977. Unity and Diversity in the New Testament. London: SCM.

Greenman, J. P, Larsen, T, \& Spencer, S. (Eds.)

2007. The Sermon on the Mount through the Centuries. From the Early Church to John Paul II. Michegan: Brazos Press. 
INGE, W.

1899. Christian Mysticism. London: Rider \& Company.

1947. Mysticism in Religion. London: Rider \& Company.

JOHNSON, L.T.

1988. Faith Misguided: Exposing the Dangers of Mysticism. Chicago: Moody Press.

KatZ, S (ED.)

1978. Mysticism and Philosophical Analysis. London: Sheldon Press.

Models, modeling and mystical training. Religion 12:247-275.

1983. Mysticism and Religious Traditions. New York: Oxford University Press.

2000. Mysticism and Sacred Scripture. Oxford: Oxford University Press.

KOURIE, C.

1985. The Historical-Critical Method in Roman Catholic Biblical Scholarship. Theologia Evangelica 18 (2):80-81.

1987. 'In-Christ' and Related Expressions in Paul. Theologia Evangelica 20 (2):33-43.

1992. Mysticism: A Survey of Recent Issues. Journal for the Study of Religion 5 (2):83-103.

1995. New Testament Scholarship on the Eve of the Third Millenium. Religion and Theology 2 (2):171-178.

2006. The 'turn to Spirituality'. The Spirit that Moves. Orientation and Issues in Spirituality. Acta Theologica Supplementum 8:19-37.

2009. Spirituality and the University. Verbum et Ecclesia 30 (1):148-173,

LEE, C.

1989. The Role of Mysticism within the Church as conceived by Hans Urs von Balthasar. Communio 16:105-126.

LESCHER, B \& LIEBERT, E.

2006. Exploring Christian Spirituality. Essays in Honor of Sandra M Schneiders. IHM. New York: Paulist Press.

LONERGAN. B.

1957. Insight. A Study of Human Understanding. London: Longmans.

1972. Method in Theology. New York: Herder \& Herder.

LOUTH, A.

1981. The Origins of the Christian Mystical Tradition. From Plato to Denys. Oxford: Clarendon Press.

MARION, D.

1981. Elisabeth de la Trinite et St Paul. Carmel 2-3:44-68. 
Mcginn, B \& Ferris Mcginn, P.

2003. Early Christian Mystics. The Divine Vision of the Spiritual Masters. New York: The Crossroad Publishing Company.

McGinN, B.

2008. Mystical Consciousness: A Modest Proposal. Spiritus 8 (1):44-63.

Merton, T.

1968. Zen and the Birds of Appetite. New York: New Directions.

MeYendorfF, J.

1989. Theosis in the Eastern Christian Tradition. In L. Dupre \& D. Saliers (eds.) Christian Spirituality. Post-Reformation and Modern, (London: SCM), pp.470-476.

Neyrey, J. H.

2007. Give God the Glory. Ancient Prayer and Worship in Cultural Perspective. Grand Rapids, Michegan: William B. Eerdmans Publishing Company.

O'KEEFE, J.

2010. Origen (c.185-c.253). Commentary on the Song of Songs. In A. Holder (ed.) Christian Spirituality. The Classics, (London: Routledge), pp 1-13.

Oropeza, B.J, Robertson, C.K. \& Mohrmann, D.C. 2009. Jesus and Paul. Global Perspectives in Honor of James D.G. Dunn. A Festschrift for his $70^{\text {th }}$ birthday. London: T\&T Clark International.

PANNIKAR, R.

1989. The Silence of God. The Answer of the Buddha. New York: Orbis Books.

Penna, R.

1996. Paul the Apostle. Wisdom and Folly of the Cross. Collegeville: The Liturgical Press.

Perrin, D.

2005. Mysticism. In A. Holder (ed.). The Blackwell Companion to Christian Spirituality. (Oxford: Blackwell Publishing Ltd.), pp. 442-458.

Ricoeur, P.

1976. Interpretation Theory: Discourse and the Surplus of Meaning. Fort Worth:

Texas Christian University.

Ricoeur, P.

1980. Essays on Biblical Interpretation. Philadephia: Fortress Press.

Ricoeur, P.

1981. Hermeneutics and the human sciences. Cambridge: Cambridge University Press.

SCHNEIDERS, S.

1986. Theology and Spirituality: Strangers, Rivals or Partners? Horizons 13 (2): 253-274. 
1989. Spirituality and the Academy. Theological Studies 50:676-697

2005a. Exegesis, Spiritual. In P. Sheldrake (ed.). The New SCM Dictionary of Christian Spirituality, (London: SCM Press), pp. 293-294.

2005b. Spirituality and Scripture. In P. Sheldrake (ed.). The New SCM Dictionary of Christian Spirituality, (London: SCM Press), pp. 62-67.

SCHWEITZER, A.

1931. The Mysticism of Paul the Apostle. London: A \& C Black Ltd. (Translation of Die Mystik des Apostels Paulus. Tubingen: Mohr).

TAVARD, G.

1981. The Christology of the Mystics. Theological Studies 42:561-579.

THeissen, G.

1987. Psychological aspects of Paul's theology. Philadelphia: Fortress.

2007. The Bible and Contemporary Culture. Minneapolis: Fortress Press.

THOMSEN, M.

1988. Jesus Crucified and the Mission of the Church. International Review of Mission 77:247-264.

THURSTON, B.

2000. The Study of the New Testament and the Study of Christian Spirituality: Some Reflections. Christian Spirituality Bulletin 8 (2):1-6.

2005. The New Testament in Christian Spirituality. In A. Holder (ed.) The Blackwell Companion to Christian Spirituality, (Oxford: Blackwell Publishing Ltd), pp. 55-70.

UNDERHILL, E.

[1911]1961. Mysticism. A Study in the Nature of Man's Spiritual Consciousness. New York: Dutton.

WAAIJMAN, K.

1992. Gathered around Scripture. A Method for Reading Scripture Together. Leuven: Boxtel.

2002. Spirituality. Forms, Foundations, Methods. Leuven: Peeters.

WANSBROUGH, $\mathrm{H}$.

2010. The Use and Abuse of the Bible. A Brief History of Biblical Interpretation. London: T\&T Clark International.

Keywords

Biblical Spirituality

Mysticism

Origen
Trefwoorde

Bybelse Spiritualiteit

Mistiek

Origenes 
Acta Theologica Supplementum 15

Elisabeth Catez Elisabeth Catez

Pauline Mysticism Pauliniese Mistiek 